\title{
RELIGION, THE LAW , AND MEDICAL ETHICS
}

\section{Religious meddling: a comment on Skene and Parker}

\section{A J Coady}

Correspondence to:

Professor C A J Coady,

Centre for Applied

Philosophy and Public

Ethics, University of

Melbourne, Victoria 3010;

t.coady@unimelb.edu.au

The question of churches resorting to the courts to influence public policy is one that concerns the appropriate role of the courts and the appropriate conduct of religious authorities. I agree with Skene

Revised version received 15 January 2002

Accepted for publication

16 January 2002 and Parker that there is no principled legal reason to exclude such interventions out of hand; but my comments are principally addressed to the political and religious reasons for being rightly concerned about such activity. These advert both to the nature of the liberal democratic compromise and to the nature and scope of religious authority (at least within Christianity).

R eviewing some recent legal cases in Australia and the UK in which organised churches have had recourse to the courts in pursuit of their religious interests in civil and political matters, Skene and Parker conclude somewhat reluctantly that they cannot find any decisive reason to deny the churches such access. ${ }^{1}$ I think that there is no such principled reason, but this tells us more about the proper role of the law rather than the proper role of the churches. They are right to be uneasy about the prospect of increased interventions by the churches in legal and constitutional matters, but this is not because such interventions are or should be somehow prohibited by law. There are many bad things, disturbing customs and illegitimate practices that should not or need not be illegal or legally controlled. What follows is concerned principally with the role of church authorities, not the practice of religious people. This seems to me an important distinction, insufficiently treated by Skene and Parker. I agree with them that religion cannot be made an entirely private matter, and that politicians, lawyers, and sundry others will be influenced in their beliefs and behaviour in all areas of life by their religious convictions. But this point has no direct connection with answering questions about the appropriate conduct of religious authorities in the public space of a democratic society.

In relation to the practices of the courts, my own view (and I do not speak as a lawyer, but a philosopher) is that the bias of the courts should be towards more access and more entitlements to be heard rather than fewer. So a relaxed attitude to the amicus conditions is something with which I am initially sympathetic. This bias seems to me an implication of commitment to democratic ideals. The fact, noted by Skene and Parker, that the rich have much more access to the legal system for securing their rights than do the poor is not just a fact of life (as they seem to suggest) but an affront to democratic values. The reduction of government commitment to legal aid, so characteristic of some Western democracies in recent years, merely compounds the offence. Of course, any bias towards access and openness needs to be balanced by the rights to fair treatment of the accused or of the parties in civil matters and by practical considerations. The laws of evidence often act to prevent certain people from being heard on certain matters and restrict what material can be put before the court. This sometimes makes little sense in terms of logic and epistemology but more in terms of protecting the citizen against the power of the state. Similarly, there are sometimes practical reasons for disallowing access on grounds of lack of standing, so that the vexatious or the frivolous, for example, do not waste valuable court time.

If the organised churches believe they have a contribution to make through the courts, or that they can influence public

policy through constitutional and other legal challenges, then the legal system should not disallow this out of hand. But this does not mean the churches are always right to make this use of the legal system. There may be several reasons why they shouldn't do so. One is prudential: in modern pluralist societies there is likely to be a degree of suspicion of anything that looks like churches attempting to impose their specifically religious views of moral behaviour on those citizens who do not share their creed. It may be politically wise for religious authorities to avoid even the appearance of this imposition lest it fan anti-religious sentiments. The Australian Catholic bishops' recourse to the High Court in the matter of infertility law may well be a case of this sort. But there are more principled worries. Some of these are concerned with the nature of a liberal democracy and others are based on theological or broadly religious considerations, though of course there is an overlap. First of all, the relevance of liberal democracy.

The modern liberal democratic state arose partly from the recognition that religious divisions within society were often a source of civil discord and violent strife, and hence they needed to be neutralised politically. This required some form of separation of church and state, a separation that is formal and constitutionally enshrined in some modern democratic polities but also real though less rigidly acknowledged in others. Nor is this liberal solution necessarily antagonistic to religious values, for it involves the recognition of the essentially uncoerced nature of faith and of the need to respect the dignity of those humans beings who have diverse religious convictions. Contrary to the fulminations of 19th and early 20th century popes, ${ }^{2}$ freedom of conscience in religious matters is now recognised in virtually all Christian circles as a positive good. For these reasons, liberal democratic states are so structured to avoid the imposition of religious doctrine on citizens by law or civic mandate. Philosophers debate how this structure should best be described. Some hold that the state must be "neutral" in all matters involving not only religion but any form of comprehensive moral or philosophical doctrine. Others hold that this neutrality need extend only to constitutional essentials. Others again, think that the "neutrality" doctrine goes too far, since there are certain philosophical doctrines that underpin the basis of the liberal state itself. ${ }^{3}$ However these debates are resolved, there is a clear consensus that the pluralist state cannot legislate the partial doctrines of this or that religious community. Hence, the suspicion of churches going to the courts to promote some part of their religious agenda. But again, this is no reason to prohibit their access to the court, rather it is a reason for ensuring that judges are cautious of involving the authority of the state in imposing partial religious views on the community. 
In fact, as Skene and Parker note, the Australian bishops have couched their submissions in terms that are not overtly religious. This certainly leaves room for the very strong suspicion that the explicit grounds for opposition to lesbian and single mother access to assisted reproductive technology (ART) are not the ones that really motivate the challenge. Indeed, the emphasis in the submission on the large percentage of the population the bishops purport to "represent" clearly shows that they view their intervention as somehow mandated by their religious position. It also suggests that the bishops are not averse to being perceived as heading a powerful pressure group. If so, there is the practical question whether the bishops are in any position to deliver a bloc vote or anything similar that might constitute pressure. What evidence there is, suggests Australian Catholics are nowadays no different from other citizens in their attitudes to ART, and the same is likely to be true about controversial issues, such as lesbian access to it. Moreover, the idea of a Catholic vote to be delivered by church leaders is totally anachronistic in contemporary Australia and similar democracies. For reasons mentioned below, it would also be theologically obnoxious if it did exist. None the less, the judges are in a position to assess the secular legal arguments on their merits without being overawed by the alleged political clout or mandate of the bishops.

Let me turn now to the worries based on the nature of religious authority itself. From a religious perspective there is a crucial theological issue about the sphere of religion and that of the state, and, in Christian circles, this has been hotly debated since Christ's famous pronouncement distinguishing what belongs to Caesar and what to God. A major problem is that the special genius of religion is easily corrupted by involvement in politics. When Christ says that his kingdom is not of this world, he is making a claim about the distinctive nature of religious experience, authority, and power. I shall restrict my comments on this to Christianity since I know it best, though I am confident that there are parallels (and differences, of course) in other religious traditions.

The authority that Christian leaders exercise is basically concerned with spiritual ends and, although these will include issues to do with life as a moral and political being, it has been increasingly realised that detailed dictation of correct social and political behaviour normally constitutes illegitimate use of religious authority. This illegitimacy takes two forms. First, it is wrong for the leaders to dictate to those who are not members of their flock: what authority they have does not extend to those who give it no recognition. Some might deny this, as indeed it has been denied in the past, but in contemporary societies, the issue is hardly worth pursuing since any such overt dictation would lack the prospect of success. Second, it is normally wrong for them to dictate on such matters to their own flock. This is a more interesting wrong and it has two principal sources. One of these concerns the broad differentiation of the spiritual and the political that has already been mentioned and the other concerns the inappropriate use of coercive power in religious matters. To this second source, we owe the widespread revulsion that many believers have these days towards excommunications, heresy trials, denials of sacraments, and so on. This revulsion has had the effect that such procedures have declined in frequency, and where they are employed they are highly controversial within the communities. It is therefore not surprising that attempts to use clerical power to dictate the political behaviour of communicants is even more resented. Increasingly indeed, Christian lay people disregard any claims by their religious leaders to direct their vote, proscribe membership of political parties, and so on. They want inspiration and prophetic guidance from their leaders, not autocracy. The prospect of their religious leaders resorting to the secular courts to pursue matters of social policy purportedly on behalf of their unconsulted communicants is likely to arouse suspicion even if it is not a case of coercive power exercised directly over them. And, in so far as the tactic can be seen as an attempt to exert clerical power indirectly over non-communicants, many in the wider community will also be understandably apprehensive.

As to the first source, it is not that the spiritual has no implications for the social and political, but rather that the implications are usually subtle and complex. Comprehension of them is often a matter of interpretation and is rooted in concrete experience. They are usually much better perceived by the involved laity rather than by clerical leadership. They are seldom matters that call for doctrinal or disciplinary determination by those in authority. Where church leaders go beyond statements and teaching of religious principle, moral or doctrinal, and offer detailed injunctions about political, scientific, professional, or other social issues, they tend to usurp the role of those in their community more directly involved in such matters. They also presume to adjudicate on areas that are legitimately open to debate and decision amongst the laity and indeed people of good will of various persuasions. Of course, there are extreme cases where such adjudication is called for. Where the German Catholic laity had failed to denounce and reject Hitler's racist doctrines and policies, the bishops could and should have opposed them. But even here, criticism and denunciation of Nazi principles and doctrines would have been more appropriate than excommunications and prohibition of membership in the Nazi party. Given the failure of such disciplinary measures in checking Communist party strength in postwar Italy, they would probably also have been more effective.

Let me conclude with two brief comments on Skene and Parker. First, they claim that, in the making of new law through the courts, there is no room for hearing "any putatively helpful doctrinal view" because any such view will already have been considered. They offer no argument for this sweeping thesis. In context, they seem to be saying that such doctrines were once worth putting to the court, but are no longer because all have already been considered. But this puts a limit to human (and religious) originality that is deeply implausible. Second, there is one positive aspect of the churches having overt recourse to the courts that they do not consider. This is that such recourse puts the church's attempts to influence social policy on public display. The claims, arguments, and manoeuvres of the church leadership are thus open to judicial and public scrutiny in a way that backroom lobbying and other covert techniques are not. The civic and religious dangers of the covert path are well demonstrated by the history of the notorious secret "Movement" run by Mr B A Santamaria under the mandate of the Australian Catholic bishops in the 1940s and 50s. The Movement aimed to defeat Communism in the trade unions and beyond, and to this end infiltrated the trade unions and the Australian Labor party, with the result that the party split and was denied power for another 16 years. Catholics who opposed the Movement were branded as disloyal. Against this background, the prospect of bishops and their supporters putting a case in the courts for open adjudication is positively refreshing. ${ }^{4}$

\section{REFERENCES AND NOTES}

1 Skene L, Parker M.. The role of the church in developing the law. Journal of Medical Ethics 2002;28:217-20.

2 See, for instance, most notably: Pius IX. Quanta cura [papal encyclical], 1894. See: http://www.saint-mike.org/Library/Papal_Library/PiusIX/ Encyclicals/Quanta_Cura.html Accessed 9 April 2002. Also quoted in Fielder M, Rabben L, eds. Rome has spoken: a guide to forgotten papal statements and how they have changed through the centuries. New York: Crossroad Publishing, 1998: 48

3 For discussion of some of these issues around religion and "neutrality" see Audi R, Wolterstorff N. Religion in the public square. Lanham, MD: Rowman and Littlefield, 1996. For a broader treatment of the neutrality thesis and its origins in the work of Ronald Dworkin, Bruce Ackerman and to some extent John Rawls, see Sher G. Beyond neutrality: perfectionism and politics. Cambridge and New York: Cambridge University Press, 1997

4 For an excellent historical account of Mr Santamaria's astonishing operation see Duncan B. Crusade or conspiracy: Catholics and the anti-Communist struggle in Australia. Sydney, NSW: University of NSW Press, 2001. 